\title{
Total phenolic content, antioxidant activity and toxicity of aqueous extracts from selected Greek medicinal and aromatic plants
}

\author{
Efstathia Skotti, Eirini Anastasaki, Georgia Kanellou, Moschos Polissiou, \\ Petros A. Tarantilis* \\ Laboratory of Chemistry, Department of Food Science and Human Nutrition, Agricultural University of Athens, Iera Odos 75, 11855 Athens, Greece
}

\section{A R T I C L E I N F O}

\section{Article history:}

Received 9 September 2013

Received in revised form 3 December 2013

Accepted 5 December 2013

\section{Keywords:}

Toxicity

Lamiaceae

Synergism

Total phenolic content

Antioxidant activity

\begin{abstract}
A B S T R A C T
In this study, the total phenolic content, the antioxidant activity and toxicity of selected Greek medicinal aromatic namely Melissa officinalis L., Origanum vulgare L., Origanum dictamnus L., Salvia officinalis L. and Hyssopus officinalis L., were investigated under three different extraction processes. Among the plants studied, Melissa officinalis L. showed the highest values in total phenolic content $(0.985 \pm 0.001 \mathrm{mg}$ caffeic acid $/ \mathrm{mL})$ and antioxidant activity $(6.61 \pm 0.04 \mu \mathrm{mol}$ Trolox $/ \mathrm{mL})$ independently of the extraction process. Toxicity evaluation of the infusions prepared in concentrations contained in commercial portions showed that inhibition values of Origanum vulgare L. and Origanum dictamnus L. were greater than $20 \%$ thus further research is necessary. Although toxicity of plant extracts examined is not correlated to their total phenolic content and antioxidant activity, it was linked to the interaction of water soluble and volatile organic compounds. Interaction of water soluble and volatile organic compounds was evaluated through the estimation of synergism ratios (SR), where Origanum vulgare L., presented the maximum synergism $(\mathrm{SR}=4.2)$ in toxicity.
\end{abstract}

(C) 2013 Elsevier B.V. All rights reserved.

\section{Introduction}

The importance of dietary antioxidant components for the prevention of some diseases and health quality improvement has attracted much research attention through the last decade (Alvarado et al., 2006; Blasa et al., 2010; Pérez-Jiménez et al., 2008; Turkmen et al., 2005; Wootton-Beard and Ryan, 2011). Vegetables and herbal infusions have been recognized as important sources of antioxidants (Alarcón et al., 2008; Almajano et al., 2008; Chan et al., 2010). Total phenolic content, antioxidant activity and antimicrobial activity of herbal extracts are of particular interest to food industry which is looking for plant extracts with significant antimicrobial activity to be used as alternatives to conventional food preservatives (Almajano et al., 2008; Madsen and Bertelsen, 1995; Thorsen and Hildebrandt, 2003).

Plant extracts obtained by different solvents and several extraction techniques are mixtures of numerous compounds. Their possible biological activity as mixtures is being investigated through various screening models such as plant (Bouchagier et al., 2008; Bouchagier and Efthimiadis, 2010), bioassays (Daferera et al., 2003), tissue or cell culture (Wang et al., 2011), receptor enzyme

\footnotetext{
* Corresponding author. Tel.: +30 210529 4262; fax: +30 2105294265.

E-mail address: ptara@aua.gr (P.A. Tarantilis).
}

(Peelman et al., 2006) and biochromatography (He et al., 2008; Kotecha et al., 2007; Kvalheim et al., 2011).

Aqueous herbal extracts have attracted attention since they can be consumed in a daily basis as decoctions. Many Lamiaceae extracts are extensively used in traditional diet and popular medicine (Barros et al., 2011; Carrió and Vallès, 2012; Degner et al., 2009; Liolios et al., 2010; Nedorostova et al., 2009; Noorbala et al., 2005). Their therapeutic actions are assigned to biologically active polyphenol components, such as flavonoids and phenolic acids, which possess antioxidant activities (Pietta, 2000; Surveswaran et al., 2007; Zheng and Wang, 2001). However, attention should be given in case of high doses (Tajkarimi et al., 2010), since their toxicity has not yet been fully elucidated. Conforti et al. (2008) introduced Microtox ${ }^{\circledR}$ test as an evaluation tool for toxicity estimation of dietary plants extracts.

Microtox ${ }^{\circledR}$ analyzer uses the marine bioluminescent bacteria Vibrio fischeri as a reference test species and provides a sensitive, rapid, cost effective and reproducible method for the estimation of toxicity of toxicity of single compounds and mixtures of organic and inorganic compounds (Backhaus et al., 2000; Fulladosa et al., 2005; Hernando et al., 2007; Park and Que Hee, 2001), biomaterials (Bulich et al., 1990; Burton et al., 1986), without raising any ethical considerations (Conforti et al., 2008; Cotou et al., 2002; Parvez et al. 2006; Shettlemore and Bundy, 2002; Zhao et al., 1998). Conforti et al. (2008) were the first to propose its use to determine toxicity of herbal infusions and decoctions and evaluate interaction between 
water soluble and volatile compounds extracted by a non-polar organic solvent.

Recently, there is, also, an increasing interest in the evaluation of potential synergism or antagonism in antimicrobial activity (AlBayati, 2008; Endo et al., 2010; Hemaiswarya and Doble, 2009; Moon et al., 2011; Ncube et al., 2012) and antioxidant activity (Romano et al., 2009) of single compounds or mixtures. Bioluminescence inhibition test using Vibrio sp. has been used by Zhang et al. (2011) for the evaluation of toxicity antagonism or synergism in mixtures.

In the present work, aqueous extracts of medicinal and aromatic plants of Lamiaceae family, namely Melissa officinalis L., Origanum vulgare L., Origanum dictamnus L., Salvia officinalis L. and Hyssopus officinalis L., were screened in reference to their total phenolic content, antioxidant activity and toxicity, as they are representative species of the Mediterranean flora. The aim of this study is to investigate a possible correlation between total phenolic content, antioxidant activity and toxicity and the interaction of water soluble and volatile organic compounds of the plant species extracts examined.

\section{Materials and methods}

\subsection{Plant material}

Air dried samples (harvest 2010) of the Lamiaceae family were offered by Aetoloakarnania's Rural Cooperative of Aromatic, Pharmaceutical and Energy Plant Cultivators (Agrotikos Syneterismos Kalliergiton Aromatikon, Farmakeftikon, Energiakon Fyton Aetoloakarnanias, ASKAFEFA), Greece. These samples were, namely, lemon balm (Melissa officinalis L.), sage (Salvia officinalis L.), oregano (Origanum vulgare L.; chemotype carvacrol), and hyssop (Hyssopus officinalis L.). Dittany (Origanum dictamnus L.; chemotype carvacrol) was supplied from the local market in Crete, Greece. Only the leaves were used, except oregano and hyssop, for which leaves and flowers were used together. Dry plant material was stored at $-20^{\circ} \mathrm{C}$ until used.

\subsection{Materials}

2,2-Azinobis-(3-ethylbenzothiazoline-6-sulfonic

acid) diammonium salt (ABTS), 2,2-diphenyl-1-picrylhydrazyl (DPPH), were purchased from Sigma-Aldrich (St. Louis, MO, USA). FolinCiocalteau phenol reagent, potassium persulfate $\left(\mathrm{K}_{2} \mathrm{~S}_{2} \mathrm{O}_{8}\right)$, sodium carbonate $\left(\mathrm{Na}_{2} \mathrm{CO}_{3}\right)$, absolute ethanol and petroleum ether $40-60^{\circ}$ were supplied by Merck KGaA (Darmstadt, Germany), Trolox (6-hydroxy-2,5,7,8-tetramethylchroman-2-carboxylic acid) and caffeic acid were purchased from Aldrich (Steinheim, Germany).

Toxicity tests were performed using the Microtox ${ }^{\circledR}$ Toxicity analyzer model 500, equipped with 30 temperature controlled wells regulated at $15^{\circ} \mathrm{C}$ in addition with a reactivation well regulated at $5{ }^{\circ} \mathrm{C}$ used to store the bacteria suspension before dilution. Acute toxicity reagents such as Diluent (sterile $2 \%$ sodium chloride), OAS (osmotic adjusting solution $22 \%$ sodium chloride), reconstitution solution and test organisms $V$. fischeri, formerly known as Photobacterium phosphoreum, NRRL No B-11177 were supplied by Strategic Diagnostic INC.

\subsection{Preparation of extracts}

For total phenolic content and antioxidant activity assessment tests, the extracts were prepared by adding $2 \mathrm{~g}$ of individual freshly crushed herb ( $n=5)$ in $200 \mathrm{~mL}$ ( 1 cup) deionized water and steeped under three different processes. (a) at $85^{\circ} \mathrm{C}$, (b) at room temperature and, (c) at room temperature with the assistance of ultrasound water bath $(35 \mathrm{MHz})$. Each treatment lasted for $15 \mathrm{~min}$. The herbal infusions were then filtered through a Whatman filter No. 1. Prior to analysis, an aliquot was further filtrated with a PTFE filter with $0.45 \mu \mathrm{m}$ pore size.

For toxicity determination, infusions were prepared as above and were then filtrated through a nylon $0.2 \mu \mathrm{m}$ membrane filter, in order to remove any suspended material that may interfere with luminescence readings (Parvez et al., 2006).

Total phenolic content, antioxidant activity and toxicity determination was performed for all plant species. All the infusions described above were then extracted three times with petroleum ether in order to further analyze the aqueous phase derived from this extraction. Three individual preparations for each extract were prepared.

\subsection{Determination of total phenolic content}

Total phenolic content was determined in herbal infusions prior and after extraction with petroleum ether using Folin-Ciocalteu assay (Singleton et al., 1999), with some modifications. Thus $100 \mu \mathrm{L}$ of each tested infusion, $500 \mu \mathrm{L}$ of Folin-Ciocalteu reagent and $6 \mathrm{~mL}$ of deionized water were transferred in a $10 \mathrm{~mL}$ flask and mixed thoroughly. After $3 \mathrm{~min}, 1.5 \mathrm{~mL}$ of $20 \% \mathrm{Na}_{2} \mathrm{CO}_{3}$ was added in the flask which was filled to $10 \mathrm{~mL}$ with water. After two hours standing, absorbance was measured at $725 \mathrm{~nm}$. Caffeic acid was used as a standard (0-500 mg/L) and the results were expressed as mg caffeic acid per $\mathrm{mL}$. All measurements were performed in triplicate.

\subsection{Determination of antioxidant activity}

Herbal infusions were examined for antioxidant activity prior and after extraction with petroleum ether applying both the ABTS assay 2,2-azinobis-(3-ethylbenzothiazoline-6-sulfonic acid) diammonium salt (Ree et al., 1999) and the DPPH assay 2,2diphenyl-1-picrylhydrazyl radical (Surveswaran et al., 2007) with some modifications.

The ABTS radical cation $\left(\mathrm{ABTS}^{\bullet+}\right.$ ) solution was prepared by the reaction of $7 \mathrm{mM}$ ABTS and $2.45 \mathrm{mM}$ potassium persulphate, after incubation at room temperature in the dark for $12-16 \mathrm{~h}$. The $\left(\mathrm{ABTS}^{\bullet+}\right)$ solution was then diluted with ethanol to obtain an absorbance of $0.700 \pm 0.020$ at $734 \mathrm{~nm}$. After the addition of $3.0 \mathrm{~mL}$ of diluted $\left(\mathrm{ABTS}^{\bullet+}\right)$ solution $\left(\mathrm{A}_{734 \mathrm{~nm}}=0.700 \pm 0.020\right)$ to $30 \mu \mathrm{L}$ of extracts, the absorbance reading was acquired at $30^{\circ} \mathrm{C}$ exactly $t=6 \mathrm{~min}$ after initial mixing $\left(A_{\text {sample }}\right)$. Absorbance of control $(3.0 \mathrm{~mL}$ $\left(\mathrm{ABTS}^{\bullet+}\right)$ solution with $30 \mu \mathrm{L}$ water) was recorded in advance $\left(A_{\text {control }}\right)$. The percentage of absorbance inhibition at $734 \mathrm{~nm}$ was calculated using the formula:

Inhibition (\%) $=\left[\frac{A_{\text {control }}-A_{\text {sample }}}{A_{\text {control }}}\right] \times 100$

where $A_{\text {control }}$ and $A_{\text {sample }}$ are the absorbance values of the control and the test sample at $t=6 \mathrm{~min}$, respectively.

A standard curve was obtained by using Trolox standard solution at various concentrations (ranging from 0 to $15 \mu \mathrm{M}$ final concentration) in ethanol. The inhibition percentage of the test samples was compared to that of the Trolox standard and the results were expressed in terms of Trolox Equivalent Antioxidant Capacity (TEAC), as mmol Trolox equivalents per $\mathrm{mL}$. All determinations were carried out three times.

The DPPH radical $\left(\mathrm{DPPH}^{\bullet}\right)$ solution $(60 \mu \mathrm{M})$ was prepared in ethanol. The $\mathrm{DPPH}^{\bullet}$ solution had an absorbance of $0.680 \pm 0.050$ at $515 \mathrm{~nm}$. A volume of $3.0 \mathrm{~mL}$ of the $\mathrm{DPPH}^{\bullet}$ solution was mixed with $30 \mu \mathrm{L}$ of the tested extracts. The resulting solution was vigorously mixed, incubated at room temperature in the dark for $30 \mathrm{~min}$ and the absorbance was recorded at $515 \mathrm{~nm}$. The percentage of absorbance inhibition at $515 \mathrm{~nm}$ was calculated as above. 
A Trolox standard curve was obtained as above. The results were also expressed as TEAC units ( $\mu \mathrm{mol}$ Trolox equivalents per $\mathrm{mL}$. All determinations were carried out three times.

\subsection{Toxicity test}

Toxicity assessment of the plant extracts was performed according to a protocol known as Basic Test 81.9\% (AZUR, 1997) applied for aqueous samples, but with appropriate primary dilution of samples in order that the $\mathrm{EC}_{50}$ (Effective Concentration where bioluminescence inhibition is $50 \%$ ) could be obtained without extrapolation of data. A dilution factor 2.0 was used. Activated bacteria were used within 1-2 h after reconstitution, stirred sufficiently before each test. Test performance and sensitivity were monitored with a phenol standard solution. $\mathrm{pH}$ was tested in all the samples to ensure that values were in the range of $6-8$.

Dilutions and assays were performed in incubator wells at $15 \pm 0.5^{\circ} \mathrm{C}$. Color correction, by measuring testing sample and dilutions absorbance at $490 \mathrm{~nm}$ (Ashworth et al., 2010) was not applied while the absorbance values of all samples tested was negligible.

Toxicity estimations were obtained after $15 \mathrm{~min}$ exposure and expressed as $\mathrm{EC}_{50}$ value, at which $50 \%$ loss of luminescence is obtained. $\mathrm{EC}_{20}$ values (sample concentration that gives $20 \%$ luminescence inhibition) were also calculated, as described below.

Effect estimation includes the correction factor $\left(R_{t}\right)$ which is the fraction obtained when the light output of the Control (Blank) remaining after time $t\left(I_{t}\right)$ is divided by the initial light output of the untreated Control (Blank) $\left(I_{0}\right)$ :

$R_{t}=\frac{I_{t}}{I_{0}}$

$\%$ Bioluminescence inhibition $=100 \times \frac{E_{c}-E_{i}}{E_{c}}$

where $E_{c}$ is the light emission of control and $E_{i}$ is the light emission of sample.

$\%$ Effect $_{t}=\left[\frac{G_{t}}{1+G_{t}}\right] \times 100$

where $(G)$ value is the ratio of the light lost at time $(t)$ for a given time $t$ to the light remaining at time $(t)$ for a given sample concentration.

Additionally, OMNI software provided the linear correlation of Gamma $(G)$ values with sample concentration. The relationship between the concentration of a toxic material and the response of a susceptible organism, when the response is measured in terms of Gamma $(G)$ values, can be described by a linear equation for the prediction of concentration from Gamma values:

$\log C=b \log G+\log a$

This equation describes a line with a slope of $b$ and an intercept of $\log a$, in which $C$ represents concentration and $G$ the corresponding Gamma value. $\mathrm{EC}_{20}$ concentrations were calculated by placing $G=0.250$ (effect $20 \%$ ) in correlation equations. As, according to the ISO 11348 (1998) guidelines, a toxic sample shows an effect higher than $20 \%$, the above values are the maximum concentrations for which a sample can be considered as non-toxic. In case of infusions a reference volume of $200 \mathrm{~mL}$ was assumed, which is the average cup volume, and calculated the corresponding dry plant mass and compared to the commercial decoction portions that are available in markets which contain usually $2 \mathrm{~g}$ of dry plant mass. Referring to their use in nutrition, the corresponding dry plant masses for oregano, which is used as raw herb in salads it was calculated assuming a reference volume of $500 \mathrm{~mL}$ on treatment (b). In order to approach the use of herbs in cooking processes, the reference volume was assumed to be ( $5 \mathrm{~L}$ ) and evaluated on treatment (a) for oregano and sage, respectively.
All the assays were performed in triplicate. Final values were calculated as an average of the values from triplicate assay.

\subsection{Synergism evaluation}

During the extraction procedure, a small quantity of essential oil compounds is extracted into the infusion. The volatile organic compounds of the essential oil in the extracts may interact with water-soluble compounds and influence the total phenolic content, the antioxidant activity and the toxicity of samples. In order to evaluate this possible interaction, extracts prepared of all the three different treatments were further extracted with petroleum ether in order to remove the volatile organic compounds and all the assays were repeated then in triplicate. Evaluation of total phenolic content, antioxidant activity and toxicity of samples before and after the extraction with petroleum ether allowed the calculation of synergism ratios (SR) between water soluble and volatile organic compounds of the initial extract.

The synergism ratios (SR) were calculated as proposed by Hewlett and Placket (1969) and used in several cases of possible synergism evaluation (Anderson and Zhu, 2004; Otitiloju, 2002), as follows:

$\mathrm{SR}_{\text {toxicity }}=\frac{\mathrm{EC}_{50 \text {-pte }}}{\mathrm{EC}_{50 \text { infusion }}}$

where $\mathrm{EC}_{50 \text {-pte }}$ is the $\mathrm{EC}_{50}$ of the aqueous phase after the extraction with petroleum ether, and $\mathrm{EC}_{50}$ infusion is the initial $\mathrm{EC}_{50}$ of each infusion.

$$
\begin{aligned}
& \mathrm{SR}_{\text {total phenolics }}=\frac{\text { Total phenolic value }_{\text {-pte }}}{\text { Total phenolic value }_{\text {infusion }}} \\
& \mathrm{SR}_{\mathrm{DPPH}}=\frac{\text { DPPH value }_{\text {-pte }}}{\text { DPPH }_{\text {infusion }}} \\
& \mathrm{SR}_{\mathrm{ABTS}}=\frac{\text { ABTS value }_{\text {-pte }}}{\text { ABTS value }_{\text {infusion }}}
\end{aligned}
$$

where '-pte' referred to the aqueous phase after the extraction with petroleum ether.

\subsection{Statistical analysis}

Data were expressed as means \pm S.D. For statistical analysis, one-way-analysis of variance (ANOVA) was applied followed by Tukey's test. Differences were considered significant at $p<0.05$. Pearson's correlation was used to determine the correlation of antioxidant activity and toxicity versus total phenolic content. All statistical analyses were performed with SPSS version 14.0 statistical package.

The inhibitory concentration $50 \%$ was calculated using the OMNI software accompanying the Mictotox ${ }^{\circledR}$ analyzer by a dose-response curve obtained by plotting the percentage of inhibition versus the concentrations.

\section{Results}

\subsection{Total phenolic content}

Total phenolic content was estimated in both infusions and the aquatic phase derived from the extraction with petroleum ether, expressed in $\mathrm{mg}$ of caffeic acid/mL. Estimated values of total phenolic content varied from 0.052 to $0.985 \mathrm{mg}$ of caffeic acid $/ \mathrm{mL}$ (Table 1 ). Total phenolic content of infusions determined in $\mathrm{mg}$ of caffeic acid/mL ranged between $0.197-0.985$ for process (a), $0.054-0.679$ for process (b) and $0.066-0.800$ for process (c).The respective values for the aqueous phase from the extraction 
Table 1

Total phenolic content, antioxidant activity estimated by DPPH ${ }^{\bullet}$, ABTS $^{\bullet+}$ method, and Toxicity of the examined herbs and extraction processes.

\begin{tabular}{|c|c|c|c|c|c|}
\hline Sample & Treatment & $\begin{array}{l}\text { Total phenolic } \\
\text { content } \\
\text { (mg caffeic acid } / \mathrm{mL} \text { ) }\end{array}$ & $\begin{array}{l}\text { Antioxidant } \\
\text { activity DPPH• } \\
(\mu \mathrm{mol} \text { Trolox } / \mathrm{mL})\end{array}$ & $\begin{array}{l}\text { Antioxidant } \\
\text { activity ABTS } \bullet \\
(\mu \text { mol Trolox } / \mathrm{mL})\end{array}$ & $\begin{array}{l}\text { Toxicity as } \mathrm{EC}_{50}(\mathrm{mg} / \mathrm{mL}) \\
\text { after } 15 \mathrm{~min} \text { incubation } \\
\text { time }\end{array}$ \\
\hline Lemon balm & $\begin{array}{l}(a)^{a} \\
(a-p t e)^{b} \\
\text { (b) } \\
\text { (b-pte) } \\
\text { (c) } \\
\text { (c-pte) }\end{array}$ & $\begin{array}{l}0.985 \pm 0.001 \mathrm{f}^{* * *} \\
0.930 \pm 0.017 \mathrm{e} \\
0.679 \pm 0.006 \mathrm{~b} \\
0.596 \pm 0.001 \mathrm{a} \\
0.800 \pm 0.002 \mathrm{~d} \\
0.724 \pm 0.004 \mathrm{c}\end{array}$ & $\begin{array}{l}6.34 \pm 0.05 \mathrm{e} \\
6.20 \pm 0.03 \mathrm{e} \\
3.22 \pm 0.07 \mathrm{~b} \\
3.03 \pm 0.09 \mathrm{a} \\
3.76 \pm 0.05 \mathrm{~d} \\
3.38 \pm 0.06 \mathrm{c}\end{array}$ & $\begin{array}{l}6.61 \pm 0.04 \mathrm{e} \\
6.59 \pm 0.05 \mathrm{e} \\
3.83 \pm 0.03 \mathrm{~b} \\
3.42 \pm 0.02 \mathrm{a} \\
4.36 \pm 0.02 \mathrm{~d} \\
4.18 \pm 0.01 \mathrm{c}\end{array}$ & $\begin{array}{l}119.8 \pm 14.5 a \\
210.7 \pm 6.9 b \\
200.6 \pm 28.8 b \\
216.3 \pm 30.3 b \\
113.1 \pm 7.9 a \\
126.9 \pm 31.1 a\end{array}$ \\
\hline Hyssop & $\begin{array}{l}\text { (a) } \\
\text { (a-pte) } \\
\text { (b) } \\
\text { (b-pte) } \\
\text { (c) } \\
\text { (c-pte) }\end{array}$ & $\begin{array}{l}0.197 \pm 0.002 d \\
0.159 \pm 0.004 d \\
0.054 \pm 0.002 a \\
0.052 \pm 0.002 b \\
0.066 \pm 0.003 b \\
0.075 \pm 0.006 c\end{array}$ & $\begin{array}{l}1.03 \pm 0.01 d \\
0.91 \pm 0.01 b \\
0.26 \pm 0.03 a \\
0.20 \pm 0.01 a \\
0.25 \pm 0.01 a \\
0.28 \pm 0.04 a\end{array}$ & $\begin{array}{l}1.03 \pm 0.02 d \\
0.95 \pm 0.02 \mathrm{c} \\
0.35 \pm 0.02 \mathrm{a} \\
0.36 \pm 0.03 \mathrm{a} \\
0.43 \pm 0.04 \mathrm{~b} \\
0.43 \pm 0.01 \mathrm{~b}\end{array}$ & $\begin{aligned} 38.3 & \pm 3.8 \mathrm{a} \\
139.6 & \pm 23.0 \mathrm{c} \\
150.7 & \pm 7.0 \mathrm{c} \\
162.8 & \pm 1.5 \mathrm{c} \\
96.1 & \pm 14.8 \mathrm{~b} \\
101.5 & \pm 25.8 \mathrm{~b}\end{aligned}$ \\
\hline Oregano & $\begin{array}{l}\text { (a) } \\
\text { (a-pte) } \\
\text { (b) } \\
\text { (b-pte) } \\
\text { (c) } \\
\text { (c-pte) }\end{array}$ & $\begin{array}{l}0.643 \pm 0.003 f \\
0.526 \pm 0.005 e \\
0.318 \pm 0.007 c \\
0.270 \pm 0.006 a \\
0.342 \pm 0.006 d \\
0.288 \pm 0.002 b\end{array}$ & $\begin{array}{l}3.16 \pm 0.06 \mathrm{f} \\
2.83 \pm 0.01 \mathrm{e} \\
1.45 \pm 0.01 \mathrm{c} \\
1.31 \pm 0.01 \mathrm{a} \\
1.62 \pm 0.03 \mathrm{~d} \\
1.38 \pm 0.01 \mathrm{~b}\end{array}$ & $\begin{array}{l}3.35 \pm 0.01 \mathrm{f} \\
2.98 \pm 0.01 \mathrm{e} \\
1.55 \pm 0.01 \mathrm{c} \\
1.34 \pm 0.01 \mathrm{a} \\
1.73 \pm 0.01 \mathrm{~d} \\
1.44 \pm 0.02 \mathrm{~b}\end{array}$ & $\begin{aligned} 8.6 & \pm 1.9 \mathrm{a} \\
36.4 & \pm 7.5 \mathrm{~b} \\
41.0 & \pm 7.9 \mathrm{~b} \\
52.3 & \pm 5.8 \mathrm{c} \\
22.1 & \pm 2.8 \mathrm{a} \\
77.7 & \pm 23.9 \mathrm{~d}\end{aligned}$ \\
\hline Dittany & $\begin{array}{l}\text { (a) } \\
\text { (a-pte) } \\
\text { (b) } \\
\text { (b-pte) } \\
\text { (c) } \\
\text { (c-pte) }\end{array}$ & $\begin{array}{l}0.320 \pm 0.001 c \\
0.257 \pm 0.007 b \\
0.142 \pm 0.006 a \\
0.140 \pm 0.002 a \\
0.173 \pm 0.002 a \\
0.173 \pm 0.001 a\end{array}$ & $\begin{array}{l}1.50 \pm 0.01 \mathrm{e} \\
1.14 \pm 0.02 \mathrm{~d} \\
0.77 \pm 0.01 \mathrm{~b} \\
0.62 \pm 0.02 \mathrm{a} \\
0.89 \pm 0.02 \mathrm{c} \\
0.78 \pm 0.02 \mathrm{~b}\end{array}$ & $\begin{array}{l}1.61 \pm 0.01 \mathrm{f} \\
1.56 \pm 0.01 \mathrm{e} \\
0.85 \pm 0.01 \mathrm{c} \\
0.70 \pm 0.03 \mathrm{a} \\
0.90 \pm 0.01 \mathrm{~d} \\
0.80 \pm 0.01 \mathrm{~b}\end{array}$ & $\begin{aligned} 10.6 & \pm 0.3 \mathrm{a} \\
42.9 & \pm 7.3 \mathrm{~b} \\
60.5 & \pm 11.4 \mathrm{~b} \\
110.7 & \pm 5.4 \mathrm{c} \\
62.2 & \pm 7.5 \mathrm{~b} \\
96.9 & \pm 8.3 \mathrm{c}\end{aligned}$ \\
\hline Sage & $\begin{array}{l}\text { (a) } \\
\text { (a-pte) } \\
\text { (b) } \\
\text { (b-pte) } \\
\text { (c) } \\
\text { (c-pte) }\end{array}$ & $\begin{array}{l}0.331 \pm 0.005 b \\
0.320 \pm 0.010 b \\
0.086 \pm 0.005 a \\
0.083 \pm 0.003 a \\
0.102 \pm 0.020 a \\
0.095 \pm 0.003 a\end{array}$ & $\begin{array}{l}1.64 \pm 0.01 \mathrm{e} \\
1.54 \pm 0.01 \mathrm{~d} \\
0.39 \pm 0.02 \mathrm{~b} \\
0.33 \pm 0.02 \mathrm{a} \\
0.42 \pm 0.02 \mathrm{c} \\
0.34 \pm 0.01 \mathrm{a}\end{array}$ & $\begin{array}{l}1.63 \pm 0.02 \mathrm{e} \\
1.62 \pm 0.03 \mathrm{e} \\
0.50 \pm 0.02 \mathrm{~b} \\
0.45 \pm 0.01 \mathrm{a} \\
0.62 \pm 0.01 \mathrm{~d} \\
0.54 \pm 0.01 \mathrm{c}\end{array}$ & $\begin{aligned} 52.2 & \pm 3.9 \mathrm{a} \\
107.8 & \pm 25.7 \mathrm{~b} \\
199.5 & \pm 21.4 \mathrm{c} \\
198.8 & \pm 19.1 \mathrm{c} \\
137.2 & \pm 2.7 \mathrm{~b} \\
224.9 & \pm 5.3 \mathrm{c}\end{aligned}$ \\
\hline
\end{tabular}

a (a) at $85^{\circ} \mathrm{C}$, (b) at room temperature and, (c) at room temperature with the assistance of ultrasounds.

b pte indicates the aqueous phase of infusions after extraction with petroleum ether.

${ }_{* * *}$ Different letter indicates significant differences $(p<0.05)$ among treatments for the same herb sample.

with petroleum ether ranged between $0.159-0.930$ forprocess (apte), 0.052-0.596 for process (b-pte) and 0.075-0.724 $\mathrm{mg}$ of caffeic acid/200 $\mathrm{mL}$ for process (c-pte).

Results show that there is a scaling increase in total phenolic content among the species tested. Lemon balm exhibited the highest phenolic content and hyssop the lowest, regardless the extraction procedure. Very interestingly ranking remains the same in the aqueous phase after the extraction with petroleum ether for all the infusions tested (Table 1).

\subsection{Antioxidant activity}

Antioxidant activity was determined by $\mathrm{DPPH}^{\bullet}$ method and expressed as $\mu \mathrm{mol}$ Trolox $/ \mathrm{mL}$. The estimated values of antioxidant activities by $\mathrm{DPPH}^{\bullet}$, expressed as $\mu \mathrm{mol}$ Trolox/mL varied from 0.35 to 6.61 (Table 1). DPPH ${ }^{\bullet}$ antioxidant activity of infusions ranged between 1.03-6.61 for process (a), 0.35-3.83for process (b) and $0.43-4.36 \mu \mathrm{mol}$ Trolox $/ \mathrm{mL}$ for process (c). The respective values of the aqueous phase from the extraction with petroleum ether ranged between $0.95-6.59$ for process (a-pte), $0.36-3.42$ for process (b-pte) and 0.43-4.18 $\mu \mathrm{mol}$ Trolox/mL for process (c-pte).

The antioxidant activity, as determined by ABTS ${ }^{\bullet+}$ method, was also expressed as $\mu \mathrm{mol}$ Trolox/mL (Table 2). Values of antioxidant activity, estimated by ABTS $^{\bullet+}$, varied from 0.20 to $6.34 \mu \mathrm{mol}$ Trolox/mL (Table 1).

Lemon balm presented the highest values of antioxidant activity. The ranking of antioxidant activity values of plant extracts, regardless the method according to which they were determined ( $\mathrm{DPPH}^{\bullet}$ or $\mathrm{ABTS}^{\bullet+}$ ), were found to be the same with the ranking of values of the total phenolic content for the same plant extracts.

\subsection{Toxicity}

The estimated $\mathrm{EC}_{50}$ toxicity values expressed as $\mathrm{mg} / \mathrm{mL}$ (Table 1 ) varied from 8.61 to 224.87 . Toxicity of infusions ranged between 8.61-119.75 for process (a), 40.96-200.61 for process (b) and $22.09-137.19 \mathrm{mg} / \mathrm{mL}$ for process (c). The same values for the aqueous phase from the extraction with petroleum ether ranged between 36.38-210.68 forprocess (a), 52.32-216.30 for process (b) and $77.69-224.87 \mathrm{mg} / \mathrm{mL}$ for process (c).

Oregano presented the lowest $\mathrm{EC}_{50}$ values for all treatments. The highest values were obtained by lemon balm in (a), (a-pte), (b), (b-pte), and by sage in (c) and (c-pte) processes.(Table 1).

The correlation equations of Gamma values with sample concentration, provided by OMNI software, allowed to calculate the concentrations corresponding to $20 \%$ effect (Gamma value: 0.25 ) where a concentration below this value can be considered as nontoxic. Based on the above, the non-toxic levels of dry plant mass that can be used in diet were calculated (Table 2). In case of infusions, dry plant mass values referred to concentrations that cause inhibition $20 \%$ were all calculated higher than $2 \mathrm{~g}$ except oregano $(0.66 \mathrm{~g})$ and dittany $(0.81 \mathrm{~g})$. Referring to their use in nutrition, the corresponding dry plant masses for oregano, was calculated at $6.48 \mathrm{~g}$ in salads and $16.5 \mathrm{~g}$ in cooking process. For sage, the corresponding value in cooking process calculated at $94.75 \mathrm{~g}$. According to Table 4 , no correlation was established between toxicity and total phenolic content $(R=0.002)$, as well as between toxicity and antioxidant 
Table 2

Concentration that causes $20 \%$ luminescence inhibition, maximum plant mass per reference volume.

\begin{tabular}{|c|c|c|c|c|c|}
\hline & Treatment & $\begin{array}{l}\text { Concentration that causes } 20 \% \\
\text { luminescence inhibition } \\
(\mathrm{mg} / \mathrm{mL})\end{array}$ & $\begin{array}{l}\text { Plant mass per reference } \\
\text { volume that cause } 20 \% \\
\text { luminescence inhibition (g) }\end{array}$ & $\begin{array}{l}\text { Reference } \\
\text { volume }\end{array}$ & Use in diet \\
\hline Lemon balm & $\begin{array}{l}(a)^{a} \\
(b)\end{array}$ & $\begin{array}{l}48.00 \\
92.33\end{array}$ & $\begin{array}{r}9.60 \\
18.47\end{array}$ & $\begin{array}{l}200 \mathrm{~mL} \\
200 \mathrm{~mL}\end{array}$ & $\begin{array}{l}\text { Decoction } \\
-\end{array}$ \\
\hline Hyssop & $\begin{array}{l}\text { (a) } \\
\text { (b) }\end{array}$ & $\begin{array}{l}11.90 \\
65.10\end{array}$ & $\begin{array}{r}2.38 \\
13.02\end{array}$ & $\begin{array}{l}200 \mathrm{~mL} \\
200 \mathrm{~mL}\end{array}$ & $\begin{array}{l}\text { Decoction } \\
\text { - }\end{array}$ \\
\hline Oregano & $\begin{array}{l}\text { (a) } \\
\text { (b) }\end{array}$ & $\begin{array}{r}3.29 \\
12.95\end{array}$ & $\begin{array}{c}\mathbf{0 . 6 6} \\
16.5 \\
6.48\end{array}$ & $\begin{array}{r}200 \mathrm{~mL} \\
5000 \mathrm{~mL} \\
500 \mathrm{~mL}\end{array}$ & $\begin{array}{l}\text { Decoction } \\
\text { During cooking process } \\
\text { Raw in salads }\end{array}$ \\
\hline Dittany & $\begin{array}{l}\text { (a) } \\
\text { (b) }\end{array}$ & $\begin{array}{r}4.04 \\
21.03\end{array}$ & $\begin{array}{l}\mathbf{0 . 8 1} \\
4.21\end{array}$ & $\begin{array}{l}200 \mathrm{~mL} \\
200 \mathrm{~mL}\end{array}$ & $\begin{array}{l}\text { Decoction } \\
\text { - }\end{array}$ \\
\hline Sage & $\begin{array}{l}\text { (a) } \\
\text { (b) }\end{array}$ & $\begin{array}{l}18.95 \\
83.79\end{array}$ & $\begin{array}{r}3.79 \\
94.75 \\
16.76\end{array}$ & $\begin{array}{r}200 \mathrm{~mL} \\
5000 \mathrm{~mL} \\
200 \mathrm{~mL}\end{array}$ & $\begin{array}{l}\text { Decoction } \\
\text { During cooking process } \\
\text { - }\end{array}$ \\
\hline
\end{tabular}

Values in Bold are those that are lower than $2(\mathrm{~g})$

a (a) at $85^{\circ} \mathrm{C}$, (b) at room temperature.

activity $\left(\mathrm{R}=0.008, \mathrm{R}=0.015\right.$ for $\mathrm{DPPH}^{\bullet}$ and $\mathrm{ABTS}^{\bullet+}$ method respectively).

\subsection{Interaction of water soluble and volatile organic compounds}

According to the results of SR values calculation (Table 3), no significant interaction was observed between volatile organic and water-soluble compounds regarding the total phenolic content and the antioxidant activity (SR values $0.7-1.0$ ). In terms of toxicity, the maximum synergy was observed in oregano (4.2), dittany (4.1) and hyssop (3.6) infusions derived from process (a), indicating the strong influence of the volatile organic compounds of each plant to the toxicity of infusions. Between the treatments, for all species examined, the synergism in toxicity was more intense in process (a) and less intense in process (b), indicating that extraction temperature influenced the toxicity of extracts mainly due to the higher quantity of volatile organic compounds of essential oil that being extracted when hot water is used.

\section{Discussion}

In all samples examined, higher levels of total phenolic content were obtained when infusions were prepared at high temperature, compared to those obtained with aqueous solvent at room temperature, either with or without ultrasound assistance. Scarce literature exists for the aqueous infusions and decoctions, since most studies examined organic solvents for the extraction of polyphenols from dried parts of plants (Čanadanović-Brunet et al., 2008; Miliauskas et al., 2004; Shan et al., 2005; Kamatou et al., 2010). In this study, total phenolics were higher in lemon balm, followed by oregano, sage, dittany and finally hyssop. In comparative studies with aqueous plant extracts, lemon balm showed the highest phenolic content in relation to the others (Katalinic et al., 2006; Fecka and Turek, 2007). Among infusions of 70 different plants from Croatia, lemon balm was also the richest in phenolic compounds followed by sage (Katalinic et al., 2006). Ivanova et al. (2005), found high levels of total phenolic content in oregano and lemon balm infusions. Recently, in two studies applied the same preparation process, herbal infusions of oregano had high levels of phenolic content, followed by dittany and sage (Kaliora et al., 2014; Kogiannou et al., 2013).

Regarding the antioxidant activity, lemon balm again exhibited the highest antioxidant activity and hyssop the lowest in all three extraction processes in both methods applied, while the activities exhibited by sage and dittany were alike in the case of hot water preparation. Recently, when the $\mathrm{DPPH}^{\bullet}$ method was applied, the

Table 3

$\mathrm{SR}_{\text {toxicity }}, \mathrm{SR}_{\text {total phenolic }}, \mathrm{SR}_{\mathrm{DPPH}}$. $\mathrm{SR}_{\mathrm{ABTS} \text {.+ }}$ indexes for the studied samples.

\begin{tabular}{|c|c|c|c|c|c|c|c|c|c|}
\hline Sample & Treatment $^{\mathrm{a}}$ & $\mathrm{SR}_{\text {total phenolic }}$ & Effect $^{\mathrm{b}}$ & $\mathrm{SR}_{\mathrm{DPPH}}$ & Effect $^{\mathrm{b}}$ & $\mathrm{SR}_{\mathrm{ABTS} .+}+$ & Effect $^{\mathrm{b}}$ & $\mathrm{SR}_{\text {toxicity }}$ & Effect $^{\mathrm{c}}$ \\
\hline \multirow[t]{3}{*}{ Lemon balm } & (a) & 0.9 & Synergism & 1.0 & Additive & 1.0 & Additive & 1.8 & Synergism \\
\hline & (b) & 0.9 & Synergism & 0.9 & Synergism & 0.9 & Synergism & 1.1 & Synergism \\
\hline & (c) & 0.7 & Synergism & 0.9 & Synergism & 1.0 & Additive & 1.1 & Synergism \\
\hline \multirow[t]{3}{*}{ Hyssop } & (a) & 0.9 & Synergism & 0.9 & Synergism & 0.9 & Synergism & 3.6 & Synergism \\
\hline & (b) & 1.0 & Additive & 0.8 & Synergism & 1.0 & Additive & 1.1 & Synergism \\
\hline & (c) & 1.1 & Antagonism & 1.1 & Antagonism & 1.0 & Additive & 1.1 & Synergism \\
\hline \multirow[t]{3}{*}{ Oregano } & (a) & 0.8 & Synergism & 0.8 & Synergism & 0.9 & Synergism & 4.2 & Synergism \\
\hline & (b) & 0.8 & Synergism & 0.9 & Synergism & 0.9 & Synergism & 1.3 & Synergism \\
\hline & (c) & 0.8 & Synergism & 0.9 & Synergism & 0.8 & Synergism & 3.5 & Synergism \\
\hline \multirow[t]{3}{*}{ Dittany } & (a) & 0.8 & Synergism & 0.8 & Synergism & 1.0 & Additive & 4.1 & Synergism \\
\hline & (b) & 1.0 & Additive & 0.8 & Synergism & 0.8 & Synergism & 1.8 & Synergism \\
\hline & (c) & 1.0 & Additive & 0.9 & Synergism & 0.9 & Synergism & 1.5 & Synergism \\
\hline \multirow[t]{3}{*}{ Sage } & (a) & 1.0 & Additive & 0.9 & Synergism & 1.0 & Additive & 2.1 & Synergism \\
\hline & (b) & 1.0 & Additive & 0.9 & Synergism & 0.9 & Synergism & 1.0 & Additive \\
\hline & (c) & 0.9 & Synergism & 0.8 & Synergism & 0.9 & Synergism & 1.6 & Synergism \\
\hline
\end{tabular}

a (a) at $85^{\circ} \mathrm{C}$, (b) at room temperature and (c) at room temperature with the assistance of ultrasounds.

b In case of total phenolic content and antioxidant activity, $\mathrm{SR}<1$ indicates synergism, $\mathrm{SR}>1$ indicates antagonism and $\mathrm{SR}=1$ additive action.

c In case of toxicity, $\mathrm{SR}_{\text {toxicity }}<1$ indicates antagonism, $\mathrm{SR}_{\text {toxicity }}>1$ indicates synergism and $\mathrm{SR}=1$ additive action. 
Table 4

Correlation between total phenolic content, antioxidant activity and toxicity of plants studied.

\begin{tabular}{|c|c|c|c|c|}
\hline & $\mathrm{DPPH}^{\bullet}$ & ABTS •+ & $\begin{array}{l}\text { Total phenolic } \\
\text { content }\end{array}$ & Toxicity \\
\hline $\mathrm{DPPH}^{\bullet}$ & & 0.995 & 0.979 & 0.008 \\
\hline $\mathrm{ABTS}^{\bullet+}$ & 0.995 & & 0.986 & 0.015 \\
\hline Total phenolic content & 0.979 & 0.986 & & 0.002 \\
\hline Toxicity & 0.008 & 0.015 & 0.002 & \\
\hline
\end{tabular}

infusion of dittany had highest antioxidant activity against the sage (Kaliora et al., 2014). Using the ABTS $^{\bullet+}$ method, in a comparative study of plants used as spices, plants of Lamiaceae family showed high antioxidant activity. Sage infusion felt sort by $50 \%$ of the corresponding value of the oregano infusion (Shan et al., 2005). In the present study, the two aforementioned methods were used for the estimation of the antioxidant activity, as there is no specific standardized method yet. Several methods have been published, as well in vitro antioxidant activity determination protocols (Armstrong, 1998; Packer and Ong, 1998; Rajalakshmi and Narasimhan, 1996). No consistent results exist as the evaluation of antioxidant activity depends strongly on the assay being used. According to the results of the present study, a positive linear correlation was established between the two methods of antioxidant activity estimation (Table 4).

The correlation coefficient $(R)$ for $\mathrm{DPPH}^{\bullet}$ and $\mathrm{ABTS}^{\bullet+}$ assay was 0.995 . $R$-value was positive at the $p<0.001$ significance level, indicating that the values of antioxidant activities assayed by the two different methods were strongly correlated. Both methods are spectrophotometry-based and are widely used to measure the antioxidant activity of natural extracts based on their ability to reduce the radical cation.

The effect of extracts toward $\mathrm{DPPH}^{\bullet}$ and $\mathrm{ABTS}^{\bullet+}$ radicals indicates the presence of compounds that have the ability to interact with the free radicals by acting as an electron donor or hydrogen atoms. Numerous studies correlate the antioxidant activity of the plant extracts in the presence of phenolic compounds (Cai et al., 2006; Čanadanović-Brunet et al., 2008; Dorman et al., 2004; Li et al., 2008; Shan et al., 2005). However, other studies have come to opposite results (Kahkönen et al., 1999) and there are others that show very little correlation (Stagos et al., 2012). In the current study, positive correlation was also found between total phenolic content and antioxidant activity in all plant extracts (Table 4). The correlation coefficient $(R)$ between the antioxidant activity obtained from $\mathrm{ABTS}^{\bullet+}$ assay and the phenolic content was 0.986 and the $R$ between the antioxidant activity obtained from DPPH ${ }^{\bullet}$ assay and the phenolic content was 0.979 , which indicates that high levels of phenolic content correlate to higher antioxidant activity.

It appears that phenolic compounds extracted depend on plant species (Tavassoli and Emam Djomeh, 2011) and the solvent used (Liu et al., 2007; Moure et al., 2001). Furthermore, environmental factors such as climate, soil, irrigation, temperature range, exposure to diseases and pests, the harvest season, the way of drying and storage or even the part of the plant tissue to be used, the content of this water are parameters that should be taken into consideration (Bergonzi et al., 2001; Wang and Zheng, 2001).

The extraction procedure appears to affect total phenolic content and antioxidant activity of each plant. Extraction with hot water differs significantly from the other infusion preparation techniques (Table 1). Similar results have been previously reported indicating the efficiency of the hot water in the extraction of phenolic compounds in various types of tea (Yang et al., 2007; Venditti et al., 2010), oregano (Teixeira et al., 2013) and mushrooms (Vamanu and Nita, 2013). Studies on the use of ultrasound for the extraction of bioactive compounds from plant materials have been reported (Caniova and Brandsterova, 2001; Paniwnyk et al., 2001;
Proestos and Komaitis, 2006; Vinatoru, 2001). The possible benefits of ultrasonic extraction are mass transfer intensification, cell disruption and improved penetration of solvent to the plant tissue. The ultrasonic waves break the vegetal cells and release the cells' contents into the extraction medium. Attention should been given in the case of the system of ultrasound extraction, since the use of probe may result in the degradation of compounds through the formation of hydroxyl radicals during the sonication of the aqueous solvent (Paniwnyk et al., 2001). Lamiaceae aromatic plants included in this study are extensively used in Mediterranean diet either as decoctions or food spices and food industry which also tends to use more sophisticated extraction techniques such as ultrasounds (Vilkhu et al., 2008). The toxicity evaluation of plant extracts studied in this research provided (a) direct comparative toxicity evaluation, (b) determination of non-toxic levels for each extract, (c) comparative evaluation of three extraction procedures in terms of toxicity of the derived extracts, (d) identification of synergism or antagonism of volatile organic and water soluble compounds in the extracts.

Toxicity found not to correlate either with antioxidant activity or total phenolic content. In case of -pte extracts, where the volatile fraction has been removed, toxicity should be related with specific phenolic and flavonoid compounds extracted. The characteristic phenolic compound of Lamiaceae species is the rosmarinic acid (Lamaison et al., 1991; Pettersen and Simmonds, 2003). Rosmarinic acid content, as has determined by high performance liquid chromatography (HPLC), varied between $86 \mathrm{mg} / \mathrm{g}$ in lemon balm, $39.50 \mathrm{mg} / \mathrm{g}$ for sage, $60 \mathrm{mg} / \mathrm{g}$ for oregano and $12 \mathrm{mg} / \mathrm{g}$ for hyssop (Saltas et al., 2013). According to the rosmarinic acid values referred in literature, the toxicity cannot be attributed to rosmarinic acid while the lemon balm although contains the highest values of rosmarinic acid, found to be the least toxic compared to the other -pte treatments. From the-pte extracts higher toxicity values presented in oregano and dittany. This activity can be attributed to other phenolic compounds have been identified in common for dittany and oregano such as $\pi$-coumaric acid, ferulic acid, caffeic and vanillic acid (Chun et al., 2005; Kouri et al., 2007; Proestos et al., 2005) or flavonoids like apigenin, keampferol, quercetin, eriodictyol, taxifolin and naringenin (Chatzopoulou et al., 2010). As rosmarinic acid levels of plants examined did not also interpret toxicity variations of their aqueous extracts further investigation is necessary to identify, quantify and evaluate toxicity of the specific components in each extract.

The calculated plant mass per reference volume that cause $20 \%$ luminescence inhibition in Microtox ${ }^{\circledR}$ (Table 2), in case of lemon balm decoction was fivefold more compared to the commercial portions of $2 \mathrm{~g}$, indicated that its toxicity is negligible similarly to sage and hyssop. The corresponding plant mass of oregano and dittany decoctions was calculated at 0.66 and $0.81 \mathrm{~g}$, respectively, values that are much lower than the usual portions consumed and so moderate use is suggested until further research on maximum daily consumption portions will be completed. The calculated plant mass of oregano and sage in cooking process or in salads found too much higher compared to the actual quantity used, so their use in diet is not raising concerns.

In case of aqueous plant extracts derived through several extraction techniques, a very small quantity of essential oil compounds comes into the aqueous phase and either promotes or inhibits partially the bioactivity of water soluble compounds. The strong influence of the volatile organic compounds to the toxicity of hyssop can be addressed to the major constituents of its essential oil which are pinocamphone (49.1\%)> $\beta$-pipene (18.4\%) > isopinocamphone (9.7\%) (Shah et al., 1986; Garg et al., 1999) and have shown remarkable antimicrobial activity in vitro (Fathiazad and Hamedeyazdan, 2011). The same synergistic tendency in dittany and oregano can be attributed to their essential 
oil common constituents, such as carvacrol, $\gamma$-terpinene and $\mathrm{p}$ cymene (Daferera et al., 2000, 2002, 2003; Lolios et al., 2010), to high antimicrobial activity.

Up to day, food industry has benefited from the synergistic and/or additive effects of essential oils and their isolated components (Bassole and Juliani, 2012). These effects have also been used by pharmaceutical industry in the context of essential oils or herbal extracts and synthetic drugs (Ghavami et al., 2011; Silva et al., 2011). Identification of possible interactions between essential oil compounds and water soluble compounds in herbal extracts, in terms of total phenolics, antioxidant activity and toxicity, should provide useful information to food and pharmaceutical industry, where health safety and health improvement is of primary concern.

\section{Conclusions}

Results of this study indicate that, among the examined plant species, lemon balm presented the highest phenolic content and antioxidant activity values, whereas hyssop presented the lowest ones. The extraction procedure was found to influence significantly the total phenolic content and antioxidant activity, as differences were observed between extractions at high and room temperature. When ultrasound assisted extraction was used, an increase in phenolic content was observed. Similar results were obtained for the aquatic phase derived from the extraction with petroleum ether. A linear positive correlation was established between total phenolic content and antioxidant activity in the infusions studied.

Extraction procedures found also to influence infusions toxicity, but no correlation was detected between toxicity and the total phenolic content or antioxidant activity. The interaction between water soluble compounds and essential oil compounds was synergistic only in case of toxicity, but no significant synergism was observed between total phenol content and antioxidant activity. The toxicity of herbal extracts is vital to be further investigated, so their use in diet as antioxidant sources would be placed in safe limits for human health.

\section{Acknowledgements}

This research has been co-financed by the European Union (European Social Fund - ESF) and Greek national funds through the Operational Program "Education and Lifelong Learning" of the National Strategic Reference Framework (NSRF) - Research Funding Program: Heracleitus II. Investing in knowledge society through the European Social Fund.

We thank the "Aetoloakarnania's Rural Cooperative of Aromatic, Pharmaceutical and Energy Plant Cultivators (Agrotikos Syneterismos Kalliergiton Aromatikon, Farmakeftikon, Energiakon Fyton Aetoloakarnanias, ASKAFEFA), Greece" for providing the herb samples.

\section{References}

Al-Bayati, F.A., 2008. Synergistic antibacterial activity between Thymus vulgaris and Pimpinella anisum essential oils and methanol extracts. J. Ethnopharmacol. 116, 403-406.

Alarcón, E., Campos, A.M., Edwards, A.M., Lissi, E., López-Alarcón, C., 2008. Antioxidant capacity of herbal infusions and tea extracts: a comparison of ORAC-fluorescein and ORAC-pyrogallol red methodologies. Food Chem. 107, 1114-1119.

Almajano, M.P., Carbó, R., Jiménez, J.A.L., Gordon, M.H., 2008. Antioxidant and antimicrobial activities of tea infusions. Food Chem. 108, 55-63.

Alvarado, C., Álvarez, P., Puerto, M., Gausserès, N., Jiménez, L., De la Fuente, M., 2006. Dietary supplementation with antioxidants improves functions and decreases oxidative stress of leukocytes from prematurely aging mice. Nutrition 22, 767-777.
Anderson, T.D., Zhu, K.Y., 2004. Synergistic and antagonistic effects of atrazine on the toxicity of organophosphorodithioate and organophosphorothioate insecticides to Chironomus tentants (Diptera: Chironomidae). Pest. Biochem. Physiol. 80, 54-64.

Armstrong, D., et al., 1998. Free Radical and Antioxidant Protocols, Vol 108 of Methods in Molecular Biology. Hummanna Press, Totowa, NJ.

Ashworth, J., Nijenhuis, E., Glowacka, B., Tran, L., Schenk-Watt, L., 2010. Turbidity and color correction in the Microtox ${ }^{\mathrm{TM}}$ bioassay. Open Environ. Pollut. Toxicol. J. 2, 1-7.

AZUR, 1997. Microtox Manual, vol. 1-4. Azur Environmental (formerly Microbics Corporation), Carlsbad, CA.

Backhaus, T., Scholze, M., Grimme, L.H., 2000. The single substance and mixture toxicity of quinolones to the bioluminescent bacterium Vibrio fischeri. Aquat. Toxicol. 49, 49-61.

Barros, L., Carvalho, A.M., Ferreira, I.C.F.R., 2011. From famine plants to tasty and fragrant spices: three Lamiaceae of general dietary relevance in traditional cuisine of Trás-os-Montes (Portugal). LWT - Food Sci. Technol. 44, 543-548.

Bassole, H., Juliani, H., 2012. Essential oils in combination to their antimicrobia properties. Molecules 17, 3989-4006.

Bergonzi, M.C., Bilia, A.R., Gallori, S., Guerrini, D., Vincieri, F.F., 2001. Variability in the content of the constituents of Hypericum perforatum L. and some commercial extracts. Drug Dev. Ind. Pharm. 27, 491-497.

Blasa, M., Gennari, L., Angelino, D., Ningali, P., 2010. Fruit and vegetable antioxidants in health. In: Watson, R., Preedy, V. (Eds.), Bioactive Foods in Promoting Health - Fruits and Vegetables. Academic Press, Massachusetts, pp. 37-58.

Bouchagier, P., Efthimiadou, A., Katsileros, A., Bilalis, D., Efthimiadis, P., 2008. Adverse effect of bermudagrass on physiological and growth components of cotton. J Agron. 7 (1), 49-55.

Bouchagier, P., Efthimiadis, P., 2010. Allelopathic susceptibility of cotton to bermudagrass. J. Agron. 9 (1), 23-28.

Bulich, A., Tung, K., Scheibner, G., 1990. The luminescent bacteria toxicity test: its potential as an in vitro alternative. J. Biolumin. Chemilumin. 5, 71-77.

Burton, S.A., Petersen, R.V., Dickman, S.N., Nelson, J.R., 1986. Comparison of in vitro bacterial bioluminescence and tissue culture bioassays and in vivo tests for evaluating acute toxicity of biomaterials. J. Biomed. Mater. Resour. 20, 827-837.

Cai, Y.Z., Sun, M., Xing, J., Luo, Q., Corke, H., 2006. Structure-radical scavenging activity relationships of phenolic compounds from traditional Chinese medicinal plants. Life Sci. 78, 2872-2888.

Čanadanović-Brunet, J., Ćetković, G., Djilas, S., Tumbas, V., Bogdanović, G., Mandić, A., Markov, S., Cvetković, D., Čanadanović, V., 2008. Radical scavenging, antibacterial, and antiproliferative activities of Melissa officinalis L. extracts. J. Med. Food $11,133-143$

Caniova, A., Brandsterova, E., 2001. HPLC analysis of phenolic acids in Melissa officinalis. J. Liq. Chromatogr. Relat. Technol. 24 (17), 2647-2659.

Carrió, E., Vallès, J., 2012. Ethnobotany of medicinal plants used in Eastern Mallorca (Balearic Islands, Mediterranean Sea). J. Ethnopharmacol. 141, 1021-1040.

Chan, E.W.C., Lim, Y.Y., Chong, K.L., Tan, J.B.L., Wong, S.K., 2010. Antioxidant properties of tropical and temperate herbal teas. J. Food Compos. Anal. 23, 185-189.

Chatzopoulou, A., Karioti, A., Gousiadou, C., Lax Vivancos, V., Kyriazopoulos, P., Golegou, S., Skaltsa, H., 2010. Depsides and other polar constituents from Origanum dictammus L. and their in vitro antimicrobial activity in clinical strains. J. Agric. Food Chem. 58, 6064-6068.

Chun, S.-S., Vattem, D.A., Lin, Y.-T., Shetty, K., 2005. Phenolic antioxidants from clonal oregano (Origanum vulgare) with antimicrobial activity against Helicobacter pylori. Proc. Biochem. 40, 809-816.

Conforti, F., Ioele, G., Statti, G.A., Marrelli, M., Ragno, G., Menichini, F. 2008. Antiproliferative activity against human tumor cell lines and toxicity test on Mediterranean dietary plants. Food Chem. Toxicol. 46, 3325-3332

Cotou, E., Papathanassiou, E., Tsangaris, C., 2002. Assessing the quality of marine coastal environments: comparison of scope for growth and Microtox ${ }^{\circledR}$ bioassay results of pollution gradient areas in eastern Mediterranean (Greece). Environ. Pollut. 119, 141-149.

Daferera, D.J., Ziogas, B.N., Polissiou, M.G., 2000. GC-MS analysis of essential oils from some Greek aromatic plants and their fungi toxicity on Penicillium digitatum. J. Agric. Food Chem. 48, 2576-2581.

Daferera, D.J., Tarantilis, P.A., Polissiou, M.G., 2002. Characterization of essential oils from Lamiaceae species by Fourier transform Raman spectroscopy. J. Agric. Food Chem. 50, 5503-5507.

Daferera, D.J., Ziogas, B.N., Polissiou, M.G., 2003. The effectiveness of plant essential oils on the growth of Botrytis cinerea, Fusarium sp. and Clavibacter michiganensis subsp. michiganensis. Crop Prot. 22, 39-44.

Degner, S.C., Papoutsis, A.J., Romagnolo, D.F., 2009. Health benefits of traditional culinary of medicinal Mediterranean plants. In: Watson, R. (Ed.), Complementary and Alternative Therapies of the Aging Population. Academic Publishing, Massachusetts, pp. 541-562.

Dorman, D.H.J., Bachmayer, O., Kosar, M., Hiltunen, R., 2004. Antioxidant properties of aqueous extracts from selected Lamiaceae species grown in Turkey. J. Agric Food Chem. 52, 762-770.

Endo, E.H., Cortez, D.A.G., Ueda-Nakamura, T., Nakamura, C.V., Filho, B.P.D., 2010 Potent antifungal activity of extracts and pure compound isolated from pomegranate peels and synergism with fluconazole against Candida albicans. Res. Microbiol. 161, 534-540. 
Fathiazad, F., Hamedeyazdan, S., 2011. A review on Hyssopus officinalis L.: composition and biological activities. Afr. J. Pharm. Pharmacol. 5 (17), 1959-1966.

Fecka, I., Turek, S., 2007. Determination of water-soluble polyphenolic compounds in commercial herbal teas from Lamiaceae: Peppermint, Melissa, and Sage. J. Agric. Food Chem. 55, 10908-10917.

Fulladosa, E., Murat, J.C., Villaescusa, I., 2005. Study on the toxicity of binary equitoxic mixtures of metals using the luminescent bacteria Vibrio fischeri as a biological target. Chemosphere 58, 551-557.

Garg, S., Nagvi, A.A., Singh, H.A., Aggarvals, S., Byers, L.D., Ensley, H.E., Gupta, S., 1999. Composition of essential oil from an annual crop of Hyssopus officinalis grown in India plains. Flavor Fragrance J. 14, 170-172.

Ghavami, G., Sardari, S., Shokrgozar, M., 2011. Cheminformatics-based selection and synergism of herbal extracts with anticancer agents on drug resistance tumor cells - ACHN and A2780/CP cell lines. Comput. Biol. Med. 41, 665-674.

He, Z.G., Sun, J., Wu, X., Lu, R., Liu, J.F., Wang, Y.J., 2008. Profiling drug membrane permeability and activity via biopartitioning chromatography. Curr. Drug Metab. 9, 152-166.

Hemaiswarya, S., Doble, M., 2009. Synergistic interaction of eugenol with antibiotics against Gram negative bacteria. Phytomedicine 16, 997-1005

Hernando, M.D., De Vettori, S., Martinez Bueno, M.J., Fernández-Alba, A.R., 2007. Toxicity evaluation with Vibrio fischeri test of organic chemicals used in aquaculture. Chemosphere 68, 724-730.

Hewlett, P.S., Placket, R.L., 1969. A unified theory for quantal responses to mixtures of drugs: non-interactive action. Biometrics 15, 591-610.

Ivanova, D., Gerova, D., Chervenkov, T., Yankova, T., 2005. Polyphenols and antioxidant capacity of Bulgarian medicinal plants. J. Ethnopharmacol. 96, $145-150$

Kahkönen, M., Hopia, A., Vuorella, H.J., 1999. Antioxidant activity of plant extracts containing phenolic compounds. J. Agric. Food Chem. 47, 3954-3962.

Kaliora, A.C., Kogiannou, D.A.A., Kefalas, P., Issidora, S., Papassideri, I.S., Kalogeropoulos, N., 2014. Phenolic profiles and antioxidant and anticarcinogenic activities of Greek herbal infusions; balancing delight and chemoprevention? Food Chem. $142,233-241$.

Kamatou, G.P.P., Viljoen, A.M., Steenkamp, P., 2010. Antioxidant, antiinflammatory activities and HPLC analysis of South African Salvia species. Food Chem. 119, 684-688.

Katalinic, V., Milos, M., Kulisic, T., Jukic, M., 2006. Screening of 70 medicinal plant extracts for antioxidant capacity and total phenols. Food Chem. 94, 550-557.

Kogiannou, D.A.A., Kalogeropoulos, N., Kefalas, P., Polissiou, M.G., Kaliora, A.C., 2013. Herbal infusions; their phenolic profile, antioxidant and antiinflammatory effects in HT29 and PC3 cells. Food Chem. Toxicol. 61, 152-159.

Kotecha, J., Shah, S., Rathod, I., Subbaiah, G., 2007. Relationship between immobilized artificial membrane chromatographic retention and human oral absorption of structurally diverse drugs. Int. J. Pharmacol. 333, 127-135

Kouri, G., Tsimogiannis, D., Bardouki, H., Oreopoulou, V., 2007. Extraction and analysis of antioxidant components from Origanum dictamnus. Inn. Food Sci. Emerg. Technol. 8, 155-162.

Kvalheim, M., Chan, H., Benzie, I., Szeto, Y., Tzang, A., Mok, D., Chau, F., 2011. Chromatographic profiling and multivariate analysis for screening and quantifying the contributions from individual components to the bioactive signature in natural products. Chemom. Intell. Lab. Syst. 107, 98-105.

Lamaison, J.L., Petitjean-Freytet, C., Carnat, A., 1991. Medicinal Lamiaceae with antioxidant properties, a potential source of rosmarinic acid. Pharm. Acta Helv. $66,185-188$

Li, H.-B., Wong, C.-C., Cheng, K.-W., Chen, F., 2008. Antioxidant properties in vitro and total phenolic contents in methanol extracts from medicinal plants. LWT 41, 385-390.

Liolios, C.C., Graikou, K., Skaltsa, E., Chinou, I., 2010. Dittany of Crete: a botanical and ethnopharmacological review. J. Ethnopharmacol. 131, 229-241.

Liu, X., Dong, M., Chen, X., Jiang, M., Lv, X., Yan, G., 2007. Antioxidant activity and phenolics of an endophytic Xylaria sp. from Gingko biloba. J. Food Chem. 105, 548-554.

Madsen, H.L., Bertelsen, G., 1995. Review: spices as antioxidants. Trends Food Sci. Technol. 64, 271-277.

Miliauskas, G., Venskutonis, P.R., van Beekb, T.A., 2004. Screening of radical scavenging activity of some medicinal and aromatic plant extracts. Food Chem. 85, 231-237.

Moon, S.E., Kim, H.Y., Dha, J.D., 2011. Synergistic effect between clove oil and its major compounds and antibiotics against oral bacteria. Arch. Oral Biol. 56, 907-916.

Moure, A., Cruz, J.M., Franco, D., Domínguez, J.M., Sineiro, J., Domínguez, H., Núnez, M.J., Parajó, J.C., 2001. Natural antioxidants from residual sources. Food Chem. 72, 145-171.

Ncube, B., Finnie, J.F., Van Staden, J., 2012. In vitro antimicrobial synergism within plant extract combinations from three South African medicinal bulbs. J. Ethnopharmacol. 139, 81-89.

Nedorostova, L., Kloucek, P., Kokoska, L., Stolcova, M., Pulkrabek, J., 2009. Antimicrobial properties of selected essential oils in vapour phase against foodborne bacteria. Food Control 20, 157-160.

Noorbala, A.A., Akhondzadeh, S., Tahmacebi-Pour, N., Jamshidi, A.H., 2005. Hydroalcoholic extract of Crocus sativus L. versus fluoxetine in the treatment of mild to moderate depression: a double-blind, randomized pilot trial. J. Ethnopharmacol. $97,281-284$
Otitiloju, A.A., 2002. Evaluation of the joint action toxicity of binary mixtures of heavy metals against the mangrove periwinkle Tympanotonus fuscatus var radula (L.) Ecotoxicol. Environ. Saf. 53, 404-415.

Packer, L., Ong, A.S.H., 1998. Biological Oxidants: Molecular Mechanisms and Health Effects. AOCS Press, Champaign, IL.

Paniwnyk, L., Beaufoy, E., Lorimer, J.P., Mason, T.J., 2001. The extraction of rutin from flower buds of Sophora japonica. Ultrason. Sonochem. 8, 299-301.

Park, K., Que Hee, S., 2001. Effect of dust on the viability of Vibrio fischeri in the Microtox test. Ecotoxicol. Environ. Saf. 50, 189-195.

Parvez, S., Venkataraman, C., Mukherji, S., 2006. A review on advantages of implementing luminescence inhibition test (Vibrio fischeri) for acute toxicity prediction of chemicals. Environ. Int. 32, 265-268.

Peelman, F., Couturier, C., Dam, J., Zabeau, L., Tavernier, J., Jockers, R., 2006 Techniques: new pharmacological perspectives for the leptin receptor. Trends Pharmacol. Sci. 27 (4), 218-225.

Pérez-Jiménez, J., Serrano, J., Tabernero, M., Arranz, S., Díaz-Rubio, M.E., García-Diz, L., Goñi, I., Saura-Calixto, F., 2008. Effects of grape antioxidant dietary fiber in cardiovascular disease risk factors. Nutrition 24, 646-653.

Pettersen, M., Simmonds, M.S.J., 2003. Rosmarinic acid. Phytochemistry 45, 1165-1172.

Pietta, P.G., 2000. Flavonoids as antioxidants. J. Nat. Prod. 63, 1035-1042.

Proestos, C., Chorianopoulos, N., Nychas, G.-J.E., Komaitis, M., 2005. RP-HPLC analysis of the phenolic compounds of plant extracts. Investigation of their antioxidant capacity and antimicrobial activity. J. Agric. Food Chem. 53, 1190-1195.

Proestos, C., Komaitis, M., 2006. Ultrasonically assisted extraction of phenolic compounds from aromatic plants: comparison with conventional extraction techniques. J. Food Qual. 29, 567-582.

Rajalakshmi, D., Narasimhan, S., 1996. Food antioxidants: sources and methods of evaluation. In: Madhavi, D.L., Deshpande, S.S., Salunkhe, D.K. (Eds.), Food Antioxidants. Marcel Dekker, New York, pp. 65-157.

Ree, R., Pellegrini, N., Proteggente, A., Pannala, A., Yang, M., Rice-Evans, C., 1999. Free Radic. Biol. Med. 26, 1231-1237.

Romano, C.S., Abadi, K., Repetto, V., Vojnov, A.A., Moreno, S., 2009. Synergistic antioxidant and antibacterial activity of rosemary plus butylated derivatives. Food Chem. 115, 456-461.

Saltas, D., Pappas, C.S., Daferera, D., Tarantilis, P.A., Polissiou, M.G., 2013. Direct determination of rosmarinic acid in Lamiaceae herbs using diffuse reflectance infrared Fourier transform spectroscopy (DRIFTS) and chemometrics. J. Agric. Food Chem. 61, 3235-3241.

Shah, N.C., Kahol, A.P., Sen, T., Uniyal, G.C., 1986. Gas chromatographic examination of Hyssopus officinalis. Parfumerie und Kos 67, 116-118.

Shan, B., Cai, Y.Z., Sun, M., Corke, H., 2005. Antioxidant capacity of 26 spice extracts and characterization of their phenolic constituents. J. Agric. Food Chem. 53, 7749-7759.

Shettlemore, M.G., Bundy, K.J., 2002. Assessment of dental material degradation product toxicity using a bioluminescent bacterial assay. Dent. Mater. 18, 445-453.

Silva, F., Ferreira, S., Duarte, A., Mendonca, D., Domingues, F., 2011. Antifungal activity of Coriandrum sativum essential oil, its mode of action against Candida species and potential synergism with amphotericin B. Phytomedicine 19, 42-47.

Singleton, V.L., Orthofer, R., Lamuela-Raventos, R.M., 1999. Analysis of total phenols and other oxidation substrates and antioxidants by means of Folin-Ciocalteu reagent. Methods Enzymol. 299, 152-178.

Stagos, D., Portesis, N., Spanou, C., Mossialos, D., Aligiannis, N., Chaita, E., Panagoulis, C., Reri, E., Skaltsounis, L., Tsatsakis, A.M., Kouretas, D., 2012. Correlation of total polyphenolic content with antioxidant and antibacterial activity of 24 extracts from Greek domestic Lamiaceae species. Food Chem. Toxicol. 50, 4115-4124.

Surveswaran, S., Cai, Y.-Z., Corke, H., Sun, M., 2007. Systematic evaluation of natural phenolic antioxidants from 133 Indian medicinal plants. Food Chem. 102 938-953.

Tajkarimi, M.M., Ibrahim, S.A., Cliver, D.O., 2010. Antimicrobial herb and spice compounds in food. Food Control 21, 1199-1218.

Tavassoli, S., Emam Djomeh, Z., 2011. Total phenols, antioxidant potential and antimicrobial activity of methanol extract of rosemary (Rosmarinus officinalis L.). Global Vet. 7, 337-341

Teixeira, B., Marques, A., Cristina Ramos, C., Serrano, C., Matos, O., Neng, N.R., Nogueira, J.M.F., Saraiva, J.A., Nunes, M.L., 2013. Chemical composition and bioactivity of different oregano (Origanum vulgare) extracts and essential oil. J. Sci. Food Agric. 93, 2707-2714.

Thorsen, M.A., Hildebrandt, K.S., 2003. Quantitative determination of phenolic diterpenes in rosemary extracts, aspects of accurate quantification. J. Chromatogr. A 995, 119-125.

Turkmen, N., Sari, F., Velioglu, Y.S., 2005. The effect of cooking methods on total phenolics and antioxidant activity of selected green vegetables. Food Chem. 93, 713-718.

Yang, D.-J., Hwang, L.S., Lin, J.-T., 2007. Effects of different steeping methods and storage on caffeine, catechins and gallic acid in bag tea infusions. J. Chromatogr. A 1156, 312-320.

Vamanu, E., Nita, S., 2013. Antioxidant Capacity and the Correlation with Major Phenolic Compounds, Anthocyanin, and Tocopherol Content in Various Extracts from the Wild Edible Boletus edulis Mushroom. BioMed Research International, Article ID 313905.

Venditti, E., Bacchetti, T., Tiano, L., Carloni, P., Greci, L., Damiani, E., 2010. Hot vs. cold water steeping of different teas: do they affect antioxidant activity? Food Chem. 119, 1597-1604. 
Vilkhu, K., Mawson, R., Simosn, L., Bates, D., 2008. Applications and opportunities for ultrasound assisted extraction in the food industry - a review. Inn. Food Sci. Emerg. Technol. 9, 161-169.

Vinatoru, M., 2001. An overview of the ultrasonically assisted extraction of bioactive principles from herbs. Ultrason. Sonochem. 8, 303-313.

Wang, B., Deng, J., Gao, Y., Zhu, L., He, R., Xu, Y., 2011. The screening toolbox of bioactive substances from natural products. A review. Fitoterapia 82, 1141-1151.

Wang, S.Y., Zheng, W., 2001. Effect of plant growth temperature on antioxidant capacity in Strawberry. J. Agric. Food Chem. 49, 4977-4982.
Wootton-Beard, P.C., Ryan, L., 2011. Improving public health? The role of antioxidant-rich fruit and vegetable beverages. Food Res. Int. 44, 3135-3148.

Zhang, J., Liu, S., Dou, R., Liu, H., Zhang, J., 2011. Evaluation of the toxicity of ionic liquid mixture with antagonism and synergism to Vibrio qinghaiensis sp.Q67. Chemosphere 82, 1024-1029.

Zhao, Y.H., Ji, G.D., Cronin, M.T.D, Dearden, J.C., 1998. QSAR study of the toxicity of benbzoic acids to Vibrio fischeri, Daphnia magna and carp. Sci. Total Environ. 216, 205-215.

Zheng, W., Wang, S.Y., 2001. Antioxidant activity and phenolic compounds in selected herbs. J. Agric. Food Chem. 49, 5165-5170. 